\title{
The Addition of Vitamin C Vaginal Tablets to Oral Metronidazole and its Effect on the Treatment and Recurrence of Bacterial Vaginosis: A Randomized Triple- Blind Clinical Trial
}

\author{
Sakineh Mohammad-Alizadeh ${ }^{1}$, Toktam Dokhanchi ${ }^{*}$, Sevil Hakimi ${ }^{1}$, Yusef Javadzadeh ${ }^{2}$, \\ Lida Takallu ${ }^{3}$, Parvin Mostafa Gharabaghi ${ }^{1}$
}

\begin{abstract}
Objectives: Bacterial vaginosis (BV) is the most common vaginitis, which is derived from a reduction in vaginal lactobacilli and an increased growth of other anaerobic species of bacteria. Vitamin C can be effective in treatment of BV through the production of lactic acid. The aim of the present study was to determine the efficacy of adding vitamin $\mathrm{C}$ vaginal to metronidazole in treatment of BV.

Materials and Methods: This study was a triple-blind randomized clinical trial.

The study was carried out from July 2015 to November 2015 on 160 women who referred to gynecologic clinic of Mashhad with pure BV. They randomized into intervention and control groups. The intervention group received $500 \mathrm{mg}$ of oral metronidazole tablets twice a day along with $250 \mathrm{mg}$ vitamin $\mathrm{C}$ vaginal tablets for 7 days and the control group received the same dose of oral metronidazole along with placebo for 7 days. Amsel and Nugent criteria were analyzed prior, $10 \pm 3$, and $30 \pm 3$ days after the treatment.

Results: The cure rate, based on Amsel and Nugent criteria was $85.9 \%$ in intervention group and $52.3 \%$ in control group on day $10 \pm 3$ (odds ratio [OR]: $5.3,95 \%$ CI: 2.4 to 11.6) and $87.7 \%$ in intervention group and $41.9 \%$ in control group on day $30 \pm 3$ (OR: 9 . 8, 95\% CI: 4.2 to 22.4 ).

Conclusion: According to the results, it seems that the two-drug treatment of BV with oral metronidazole and vitamin $\mathrm{C}$ vaginal tablets is more effective than one-drug treatment of BV by oral metronidazole for recovery and non-recurrence.

Keywords: Ascorbic ccid, Bacterial vaginosis, Metronidazole
\end{abstract}

\section{Introduction}

Vaginitis is an infectious and inflammatory disease that affects vagina and is associated with abnormal vaginal discharge (1). Lactobacilli is the most common vaginal microorganism. The decrease of lactobacilli may lead to symptomatic changes in vagina. Bacterial vaginosis (BV) is the most common vaginitis that is known by a reduction in vaginal lactobacilli and an increased growth of other anaerobic species of bacteria (2). BV can be observed in $64 \%$ of women with sexually transmitted infections, $15 \%$ to $20 \%$ of pregnant women, and $10 \%$ to $15 \%$ of women who refer to gynecologic clinics $(3,4)$. BV is widespread in different parts of the world and among different ethnicities. For example, it was detected by $5 \%-15 \%$ among Caucasian women and 45\%-55\% among African and black Americans. It is estimated that the total prevalence of BV around the world is $20 \%-30 \%$. The prevalence of $\mathrm{BV}$ in Iran varies. It is reported by $16 \%$ in central, $40 \%$ in southern, and 50\% in tribes of Iran (among high-risk population) which is a significant value (5-7).

$\mathrm{BV}$ is a strong risk factor for acquiring and transmission of sexually transmitted diseases, including human immunodeficiency virus (HIV) and pelvic inflammatory disease (8). Moreover, it infects amniotic fluid and fetal membranes and causes premature rupture of membranes during pregnancy and post-partum fever $(9,10)$.

The selected treatment of BV is oral metronidazole (11). However, more than half of patients have 2 to 3 recurrences per year (12). BV affects varying degrees of self-confidence and sexual life of women (13). One of the challenges of physicians is to find the effective treatment of BV, because the long-term effectiveness of antibiotics is weak and recurrence is common (13).

The aim of BV treatment is to preserve the vaginal $\mathrm{pH}$ at 4.5 and lower and to prevent the over growth of pathogens until normal vaginal flora is reconstructed and maintain normal vaginal $\mathrm{pH}(14,15)$. The relationship between BV and increased level of vaginal $\mathrm{pH}$ has made the use of vagina acidifier materials as an attempt to build an unsuitable area for the growth of pathogens, reasonable (16). One of the effective materials in maintaining vaginal $\mathrm{pH}$ lower than 4.5 is vaginal vitamin $\mathrm{C}$; vaginal vitamin $\mathrm{C}$ maintains vaginal $\mathrm{pH}$ at low range and is effective in treatment of $\mathrm{BV}$ through producing lactic acid (17). 
Some studies have shown the effects of vaginal vitamin $\mathrm{C}$ on decreasing the signs and symptoms of BV (18-20).

This aim of this study was to determine the efficacy of vitamin $\mathrm{C}$ and metronidazole on $\mathrm{BV}$ treatment using the Amsel and Nugent criteria. The reason why vitamin $C$ is used for this study is its effectiveness in decreasing vaginal $\mathrm{pH}$, reducing the clue cells (16), maintaining normal acidity for vagina by producing lactic acid (17-19) and safe topical application of this material in human.

\section{Materials and Methods \\ Study Design}

This triple-blind randomized clinical trial was performed from July 2015 to November 2015. Recruitment was began after receiving permission from Ethics Committee of Tabriz University of Medical Sciences. All women gave a written informed consent and the vaginal samples were taken by correspondent author. Research environment included gynecological clinic of Samen hospital (specialized hospital affiliated with the armed forces) in Mashhad, a metropolitan in north eastern Iran and the capital of Khorasan-e Razavi province with a population of about 3.2 million people (21).

\section{Outcome Measures}

The primary outcomes were appropriate clinical and laboratory manifestations based on Amsel and Nugent criteria $10 \pm 3$ and $30 \pm 3$ days after the treatment, lack of malodorous discharge, itching, dyspareunia, and fishy smell during the sexual intercourse and the secondary outcomes were variation in vaginal $\mathrm{pH}$ and existence of clue cells $10 \pm 3$ and $30 \pm 3$ days after the treatment.

\section{Participants}

Inclusion criteria were: married non-pregnant and non-lactating women aged 18-45 years, diagnosis of BV based on Amsel and Nugent scoring system, willingness to participate in research and being monogamous of husband. Patients were excluded if they were affected by chronic diseases, HIV, genital herpes or other vaginal infections, and unexplained vaginal bleeding. Using vaginal drugs and vaginal douche and taking any antibiotics, rifampin, phenytoin, phenobarbital or any type of anticoagulant during the last 2 weeks.

\section{Intervention}

The data collection questionnaires included the demographic and reproductive history, clinical examination and laboratory tests.

In this study, the diagnosis of $\mathrm{BV}$ was considered in case of at least 3 components of 4 Amsel criteria, including gray vaginal discharge, positive Whiff test, vaginal $\mathrm{pH}$ more than 4.5 , the presence of clue cells $(22,23)$ and the score of 4 to 6 with clue cells or higher than 7 without clue cells, based on the Nugent scoring system (24-26). The treatment of this study was the removal of all Amsel criteria or remaining of 1 criterion, as well as getting the scores of 0 to 3 or 4 to 6 without clue cells due to Nugent scoring system.

Women with abnormal vaginal discharge problems who referred to the gynecologic clinic were examined frequently by sterile speculum after the explanation of objective of the study. Samples of discharges were taken by sterile swab and were transferred on 2 separate slides. The first slide was evaluated after adding a drop of $1 \%$ potassium hydroxide in terms of amine smell release (Whiff test) and the second slide was sent to the laboratory at the same day for due microscopic examinations. The $\mathrm{pH}$ of vaginal discharge was measured using $\mathrm{pH}$ meter tape (Merck, Germany) with 0.5 precision. The slides were Gram stained by the technician, who was unaware of Amsel criteria results and allocation of people in the groups. People with definite diagnosis of BV were called at the same night in order to take medicine next day from the gynecologic clinic.

The intervention group took 4 oral metronidazole tablets $250 \mathrm{mg}$ daily for 7 days (given by researchers to patients [ 2 per 12 hours]) with $250 \mathrm{mg}$ vitamin $\mathrm{C}$ vaginal tablets and the control group took the same dose of oral metronidazole and placebo vaginal tablets. Patients were told about the correct use of vaginal drug and they were asked not to use the vaginal douche during drug consumption and not to take antibiotics as well as condom. The initial follow-up was after treatment on day $10 \pm 3$ and the second follow-up was treatment on day $30 \pm 3$. Patients' examination on follow-ups after treatment included vaginal examination by sterile vaginal speculum and cervix and vaginal examination in terms of inflammation and vaginal $\mathrm{pH}$ as the first examination. Furthermore, samples of discharges were taken by 2 sterile swabs for Whiff test. The satisfaction of treatment was asked from participants at the first follow-up after treatment using a 3-point Likert scale questions. Side events checklist was completed for all of participants.

\section{Sampling and Sample Size}

Sample size was calculated using Power and Sample Size Calculation (PS) software version 1.3. Considering 66\% cure rate of oral metronidazole (27), 5\% type I error and power of $80 \%$ and the dropout rate of $10 \%$, the required samples for detecting minimum of $20 \%$ difference between 2 groups in cure rate were calculated, 80 individuals per group.

\section{Randomization and Blinding}

Eligible subjects, who met the entrance criteria were allocated into 2 intervention (receiving vitamin $\mathrm{C}$ vaginal tablets and oral metronidazole) and control groups (placebo vaginal tablet and oral metronidazole) by random block with 4 and 6 blocks and allocation ratio of 1:1. The study was triple blind. It means that the treatment assignment was concealed from the participants, investigators and data analyzer.

The allocation sequence was identified using Randomized Allocation Software (RASS) version 2.0 by a person who was not involved in the study.

The patients received packs, containing 7 vitamin C 250 
mg vaginal tablets or placebo, which were written with consecutive numbers in order to respect the appropriate method for allocation concealment.

Vitamin $\mathrm{C}$ vaginal tablets were prepared using inert pharmacological excipients such as microcrystalline cellulose, starch, lactose, and magnesium stearate also containing vitamin $\mathrm{C}$ as active ingredient. Placebo tablets also contained the same ingredients except vitamin $C$ with the same shape and color completely similar in appearance (color, smell, shape) in formulation laboratory of Faculty of Pharmacy, Tabriz University of Medical Sciences.

\section{Statistical Analysis}

Data were analyzed using the SPSS software version 15 . In order to describe the sociodemographic characteristics, descriptive statistics was used (e.g. frequency) as well as central and dispersion indexes (e.g. mean and standard deviation). To compare demographic characteristics between groups independent $t$ test, chi-square and chi-square for trend were used. For calculating odds ratio (OR) binary logistic regression was used. In all measurements, the $P$ value of less than 0.05 was considered statistically significant.

\section{Results}

The initial and clinical examination was carried out on 825 women whom attended the outpatient gynecologic clinic with abnormal vaginal discharge, among which 608 patients were excluded due to lack of inclusion criteria, and 57 patients were excluded because they were not in- terested to participate in the study. The study took place with 160 women. One patient of intervention group and 2 patients of control group did not attend the first follow-up meetings. When the reasons were asked by phone, all of them stated about recovery of vaginitis and lack of the disease. Six patients of intervention group and 7 patients of control group did not attend in the second follow-up meetings. Three patients of intervention group and 4 patients of control group did not respond to calls due to pregnancy, travel, and complete treatment (Figure 1).

There was no significant difference between intervention and control groups in terms of socio-demographic characteristics (Table 1). The mean \pm standard deviation (SD) age of participants was 33.8 $\pm 7.5 .18 .8 \%$ of women were employed. $51.9 \%$ of women had high school diploma and $28.8 \%$ had higher education.

\section{Baseline Characteristics of the Participants}

At the baseline, all participants had smelly gray vaginal discharges with vaginal $\mathrm{pH}$ higher than 4.5 and positive Whiff test. Vaginal smear of $73.4 \%$ of participants included clue cells. There were no significant differences between the 2 groups in terms of clinical complaints, including smelly discharge, vaginal itching, and dysuria. There was no significant difference between the 2 groups in terms of Nugent criteria components other than number of lactobacilli and in terms of Amsel criteria components other than $\mathrm{pH}$ at the beginning of study. This means that the vaginal $\mathrm{pH}$ of control group was significantly lower than the experimental group (Table 2).

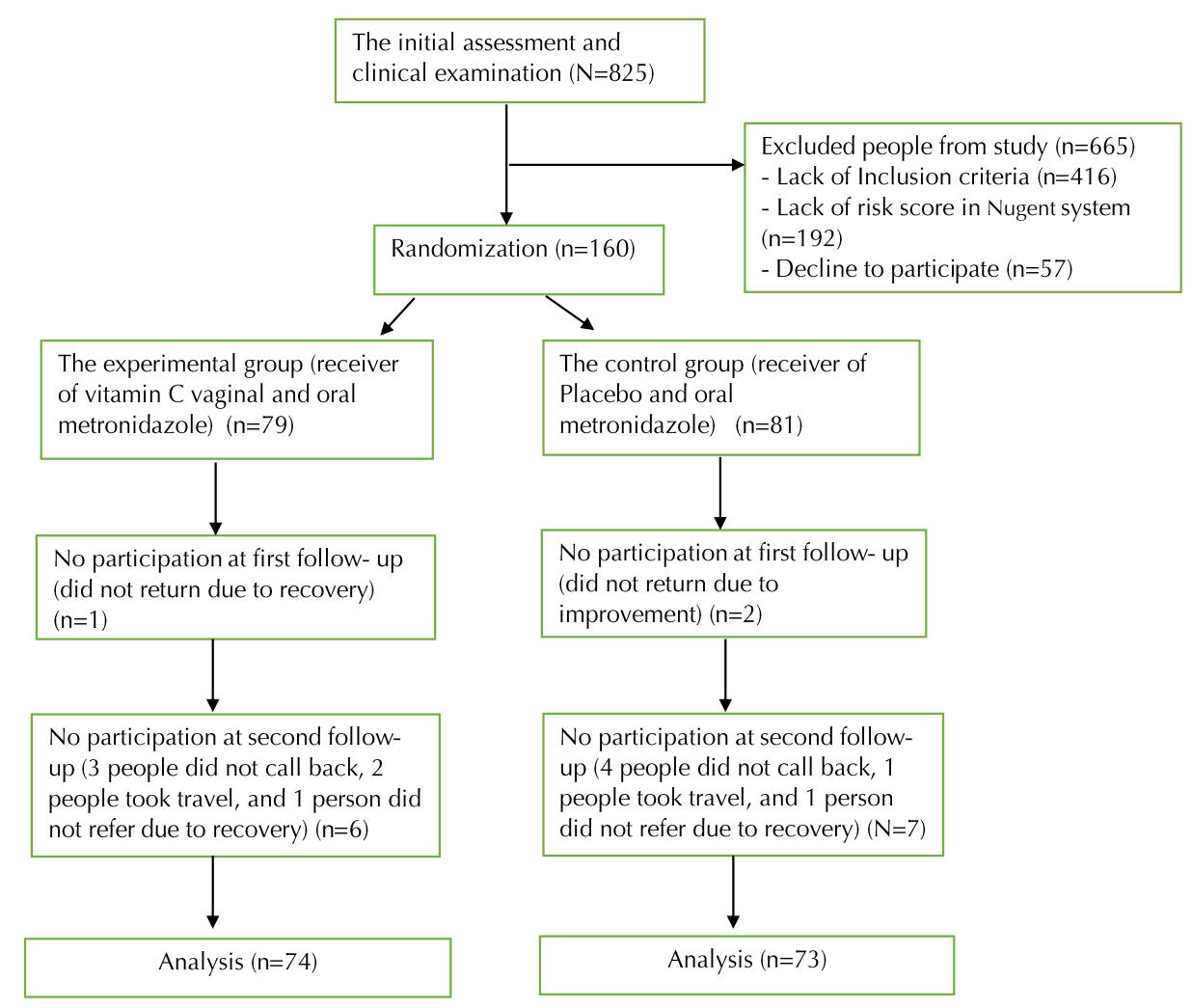

Figure 1. Study Flowchart. 
Table 1. Comparison of the Demographic Features and Midwifery History of Participants in Separate Groups

\begin{tabular}{lcc}
\hline & Vitamin C (n=79) & Placebo (n=81) \\
\hline $\begin{array}{l}\text { Age (y), Mean (SD) } \\
\text { Job, No. (\%) }\end{array}$ & $33.4(7.5)$ & $34.3(7.6)$ \\
$\quad$ Housewife & $66(83.5)$ & $0.932^{\mathrm{a}}$ \\
Education, No. (\%) & & $0.461^{\mathrm{b}}$ \\
$\quad$ Low literacy (elementary to high school) & $11(13.9)$ & $20(24.7)$ \\
$\quad$ Diploma & $43(54.4)$ & $40(49.4)$ \\
$\quad$ University & $25(31.6)$ & $21(25.9)$ \\
$\begin{array}{l}\text { Duration of marriage (y) } \\
\text { Number of gestation }\end{array}$ & $12(4.2)$ & $13(3.3)$ \\
Type of last delivery, vaginal, No. (\%) & $2.54(1.07)$ & $2.74(1.03)$ \\
Curettage history, No. (\%) & $35(55.6)$ & $43(62.3)$ \\
Cervical cautery or cryotherapy history, No. (\%) & $10(12.7)$ & $12(14.8)$ \\
Infections history over the past year, No. (\%) & $8(10.2)$ & $8(9.9)$ \\
\hline
\end{tabular}

andependent $t$ test.

${ }^{\mathrm{b}}$ Chi-square.

${ }^{\mathrm{c} C h i}$-square for trend.

Table 2. Effect of Treatment on Amsel and Nugent Ccriteria

\begin{tabular}{|c|c|c|c|c|c|c|c|c|c|c|}
\hline \multirow[b]{2}{*}{ Variables } & \multicolumn{3}{|c|}{ Vitamin C + Metronidazole } & \multicolumn{3}{|c|}{ Placebo + Metronidazole } & \multirow[b]{2}{*}{$\begin{array}{c}\text { 10th Day, OR } \\
(95 \% \mathrm{CI})\end{array}$} & \multirow[b]{2}{*}{$P$} & \multirow[b]{2}{*}{$\begin{array}{l}\text { 30th day, } \\
\text { OR (95\% } \\
\text { CI) }\end{array}$} & \multirow[b]{2}{*}{$P$} \\
\hline & $\begin{array}{c}\text { Before } \\
\text { Experimental } \\
(n=79)\end{array}$ & $\begin{array}{c}\text { 10th Day } \\
(n=78)\end{array}$ & $\begin{array}{l}\text { 30th Day } \\
(n=73)\end{array}$ & $\begin{array}{l}\text { Basic } \\
\text { Values } \\
(n=81)\end{array}$ & $\begin{array}{c}\text { 10th Day } \\
(n=79)\end{array}$ & $\begin{array}{l}\text { 30th Day } \\
(n=74)\end{array}$ & & & & \\
\hline $\begin{array}{l}\text { Treatment based } \\
\text { on Nugent and } \\
\text { Amsel criteria }\end{array}$ & & $67(85.9)$ & $64(87.7)$ & & $42(52.3)$ & 31 (41.9) & $5.3(2.4-11.6)$ & $<0.001$ & $\begin{array}{c}9.8(4.2- \\
22.74)\end{array}$ & $<0.001$ \\
\hline $\begin{array}{l}\text { Treatment based } \\
\text { on Amsel criteria }\end{array}$ & & $69(87.3)$ & $65(82.3)$ & & $43(53.1)$ & $31(38.3)$ & $6.4(2.8-14.6)$ & $<0.001$ & $\begin{array}{c}11.7(4.7- \\
26.8)\end{array}$ & $<0.001$ \\
\hline $\begin{array}{l}\text { Lack of } \\
\text { homogeneous } \\
\text { discharge }\end{array}$ & $0(0)$ & $68(87.3)$ & $55(87.3)$ & $0(0)$ & $34(39.2)$ & $48(64.9)$ & $7.2(3.40-15.5)$ & $<0.001$ & $\begin{array}{c}3.85 \text { (1.65- } \\
8.79)\end{array}$ & $<0.001$ \\
\hline Lack of clue cells & $1(26.6)$ & $70(89.7)$ & $8(93.2)$ & $34(42)$ & $46(58.2)$ & $52(70.7)$ & $\begin{array}{c}6.27(2.66- \\
14.79)\end{array}$ & $<0.001$ & $\begin{array}{c}5.64(2- \\
15.89)\end{array}$ & $<0.001$ \\
\hline $\begin{array}{l}\text { Negative Whiff } \\
\text { test }\end{array}$ & $0(0)$ & 77 (99.7) & $70(95.9)$ & $0(100)$ & $68(86.1)$ & $64(86.5)$ & $12.4(1.56-99)$ & $<0.001$ & $\begin{array}{c}3.64(0.96- \\
13.82)\end{array}$ & $<0.001$ \\
\hline $\mathrm{pH}<4.5$ & $0(0)$ & $68(87.2)$ & $60(82.2)$ & $0(0)$ & $33(41.8)$ & $24(32.4)$ & $9.4(4.2-21.1)$ & $<0.001$ & $\begin{array}{l}9.61(4.4- \\
20.28)\end{array}$ & $<0.001^{\mathrm{a}}$ \\
\hline $\begin{array}{l}\text { Treatment based } \\
\text { on Nugent criteria } \\
\text { (\%) }\end{array}$ & $0(0)$ & 71 (89.9) & $68(93.2)$ & $0(0)$ & $49(61.3)$ & $53(70.7)$ & $5.6(2.3-13.20)$ & $<0.001$ & $\begin{array}{c}5.6(2.063- \\
15.89)\end{array}$ & $<0.001^{b}$ \\
\hline
\end{tabular}

a logistic regression.

${ }^{\mathrm{b}}$ logistic regression with adjustment of baseline lactobacilli levels.

Outcomes and Estimations

The effects of treatment on Amsel, Nugent criteria and patients' complaints were summarized in Tables 2 and 3, respectively.

The cure rate of the intervention group was $85.9 \%$ on 10th day (OR: 5.3 , 95\% CI: 2.4 to 11.6 ) and was $87.7 \%$ on 30th day (OR: 9. 8, 95\% CI: 4.2 to 22.4 ). Vaginal pH between and within groups during the time was compared and results were summarized in Figure 2.

Participants were evaluated in terms of probable side effects of the treatment. Eleven subjects of the intervention group complained at early days from vaginal irritation and itching. There were no complications in the control group. Fifty-nine patients from intervention group (75.6\%) and 67 patients from control group $(84.8 \%)$ were satisfied from treatment.

\section{Discussion}

The results of this study indicated that vitamin $C$ vaginal tablets and oral metronidazole, compared with the oral metronidazole on treatment and recurrence of BV one month after starting treatment, are more effective 
Table 3. Effect of Treatment on Patient Complaints

\begin{tabular}{|c|c|c|c|c|c|c|c|c|c|c|}
\hline \multirow[b]{2}{*}{ Complaints } & \multicolumn{3}{|c|}{ Vitamin C + Metronidazole } & \multicolumn{3}{|c|}{ Placebo + Metronidazole } & \multirow{2}{*}{$\begin{array}{c}\text { 10th Day } \\
\text { OR } \\
95 \% \mathrm{Cl}\end{array}$} & \multirow{2}{*}{\multicolumn{2}{|c|}{$\begin{array}{c}\text { 30th Day } \\
\text { OR } \\
95 \% \mathrm{Cl}\end{array}$}} & \multirow[b]{2}{*}{$P$} \\
\hline & $\begin{array}{l}\text { Basic Values } \\
\qquad(n=79)\end{array}$ & $\begin{array}{c}\text { 10th Day } \\
(n=78)\end{array}$ & $\begin{array}{l}\text { 30th Day } \\
(n=73)\end{array}$ & $\begin{array}{l}\text { Basic Values } \\
\quad(n=81)\end{array}$ & $\begin{array}{c}\text { 10th Day } \\
(n=79)\end{array}$ & $\begin{array}{c}\text { 30th Day } \\
(n=74)\end{array}$ & & & & \\
\hline $\begin{array}{l}\text { Smelly } \\
\text { discharge }\end{array}$ & 79 (100\%) & $12(15.4 \%)$ & $10(13.7 \%)$ & $81(100 \%)$ & $45(\% 57)$ & $45(60.8 \%)$ & $\begin{array}{c}0.1(0.06- \\
0.29)\end{array}$ & $0.001^{\mathrm{a}}$ & $0.26(0.11-0.60)$ & $0.002^{\mathrm{a}}$ \\
\hline $\begin{array}{l}\text { Pain during } \\
\text { intercourse }\end{array}$ & $73(92.4 \%)$ & $0(0)$ & $2(2.8 \%)$ & $72(88.9 \%)$ & $0(0)$ & $2(2.8 \%)$ & $0(0-0)$ & 0.997 & $0.07(0.133-0.79)$ & 0.992 \\
\hline Itching & $73(92.4 \%)$ & $0(0)$ & $1(1.4 \%)$ & $72(90.1 \%)$ & $11(13.9 \%)$ & $11(14.9 \%)$ & $0(0-0)$ & 0.997 & $0.08(0.01-0.64)$ & $0.017^{\mathrm{a}}$ \\
\hline $\begin{array}{l}\text { Abdominal } \\
\text { pain }\end{array}$ & 45 (57\%) & $5(6.4 \%)$ & $2(2.7 \%)$ & $51(63 \%)$ & $12(15.2 \%)$ & $11(14.9 \%)$ & $\begin{array}{c}0.38(0.12- \\
1.14)\end{array}$ & 0.085 & $0.16(0.03-0.75)$ & $0.021^{\mathrm{a}}$ \\
\hline
\end{tabular}

${ }^{\text {a }}$ Logistic regression.

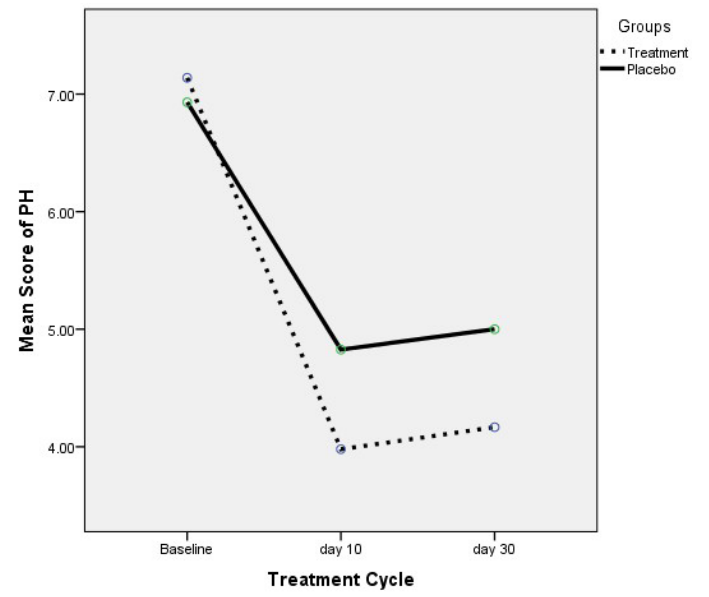

Figure 2. Comparison of Vaginal pH Between Groups During the Time.

without any serious side effects. In this study, all 4 components of Amsel criteria in the intervention group were improved compared with control group on 10th and 30th days after treatment. Microscopic examination of samples showed that the intervention group obtained better $\mathrm{Nu}-$ gent score compared to control group. This difference was statistically significant.

The results of this study were consistent with the results of other studies. Abbaspoor et al compared the efficacy of vitamin $\mathrm{C}$ vaginal tablet and metronidazole vaginal gel within 1 and 2 weeks after the treatment and in a double-blind study. Amsel criteria components were not significantly different between the 2 groups during the first and second weeks of treatment; they concluded that 250 $\mathrm{mg}$ vitamin $\mathrm{C}$ vaginal was effective in BV treatment similar to what metronidazole vaginal tablets can do (20).

The results of Petersen and colleagues' study showed that $250 \mathrm{mg}$ vitamin $\mathrm{C}$ vaginal was more effective than placebo for the reduction of clue cells, $\mathrm{pH}$ and, negative Whiff test within the first and second week after the treatment (19).

In a study by Krasnopolsky et al in treated women, there was no significant difference between BV recurrence based on Amsel criteria 3 months after treatment with 250 $\mathrm{mg}$ vitamin $\mathrm{C}$ vaginal and placebo group; but this difference was significant 6 months after the treatment (28). In this study, the difference between the 2 groups in terms of BV recurrence 3 months after the treatment was not statistically significant but difference between the 2 groups was significant (14.7\% of controls against $6.8 \%$ of experimental group).

In general, cure rate of experimental group in the current study was $88.5 \%$ on 10 th day based on Amsel criteria. The cure rate of this study was more than Abbaspoor et $\mathrm{al}(76.7 \%)$ and Petersen et al (77\%) at the end of first week. One of the possible reasons of difference is the simultaneous treatment of patients with oral metronidazole and vitamin $\mathrm{C}$ vaginal tablet. While in the studies conducted by Abbaspoor et al and Paterson et al, vitamin $\mathrm{C}$ vaginal was administered to intervention group (18-20).

The first control mechanism of normal vaginal flora is the decrease in $\mathrm{pH}$ (29). One of treatments of BV is to keep down the acidity of vagina. Anaerobic bacteria will not be able to grow within $\mathrm{pH}$ 3.8-4.5 (28). Use of antibiotics for BV treatment would lead to anaerobic bacteria resistance, treatment failure, and recurrence of $\mathrm{BV}$ within a few weeks (30). Use of vitamin C vaginal, as an extra treatment plays an important role in keeping down the $\mathrm{pH}$. In this study, the vaginal $\mathrm{pH}$ of the intervention group was $19 \%$ less than that of the control group on 30th day.

In this study, the most common side effect of vitamin C was vaginal irritation and itching. This finding is in line with other studies (18-20,28).

The satisfaction of treatment was asked from participants at the first follow-up after treatment. In the intervention group, $75.6 \%$ of participants and in the placebo group $84.8 \%$ of participants group were satisfied. One of main reasons for lack of satisfaction in the intervention group was vaginal itching and irritation after the consumption of vitamin C. In study by Polatti (31), most people were satisfied with the received treatment; besides, $75.3 \%$ of vitamin C vaginal receivers in Krasnopolsky et al (28) study described it as good or very good.

Strengths and Weaknesses

The advantages of this study include blinding partici- 
pants, researchers and data analyzer, random allocation, and simultaneous use of Amsel and Nugent criteria in BV diagnosis $(23,25)$. The weaknesses of this study included short treatment follow-ups. Further studies with longer follow-up periods are recommended.

\section{Conclusion}

According to the results, we found that combination drug treatment of BV with oral metronidazole and vitamin C vaginal tablets during 1 month is more effective than onedrug treatment of BV by oral metronidazole in treatment and relapse. Explanation about the side effects of vitamin $\mathrm{C}$ vaginal tablets leads to satisfaction of consumers, because vaginal irritation and itching are common in the early days of consumption and will reduce the consent of patients. Further studies are required for public use of this treatment during longer time.

\section{Ethical Issues}

The ethical committee of Tabriz University of Medical approved the study (No. TBZMED.REC.1394.5). Also, we registered it at the Iranian Registry of Clinical Trails website (identifier: IRCT2015042521917N3).

\section{Conflict of Interests}

The authors have no conflict of interests.

\section{Financial Support}

The research has been financially supported by Women's Reproductive Health Research Center, Tabriz University of Medical Sciences.

\section{Acknowledgments}

This research is a part of MSc thesis. Hereby, assistance and cooperation of research deputy of Tabriz University of Medical Science and the participants is appreciated.

\section{References}

1. Ryan K, Berkowit R, Barabieri LR. Kistner's Gynecology and Women's Health. Boston: Mosby Incorporated; 1999.

2. van de Wijgert $\mathrm{JH}$, Borgdorff $\mathrm{H}$, Verhelst $\mathrm{R}$, et al. The vaginal microbiota: what have we learned after a decade of molecular characterization? PloS One. 2014;9(8):e105998. doi: 10.1371/journal.pone.0105998.

3. Chaijareenont K, Sirimai K, Boriboonhirunsarn D, Kiriwat O. Accuracy of Nugent's score and each Amsel's criteria in the diagnosis of bacterial vaginosis. J Med Assoc Thai. 2004;87(11):1270-1274.

4. Fettweis JM, Brooks JP, Serrano MG, et al. Differences in vaginal microbiome in African American women versus women of European ancestry. Microbiology. 2014;160(10):2272-2282. doi: 10.1099/mic.0.081034-0.

5. Bahram A, Hamid B, Zohre T. Prevalence of bacterial vaginosis and impact of genital hygiene practices in non-pregnant women in Zanjan, Iran. Oman Med J. 2009;24(4):288-293. doi:10.5001/omj.2009.58.

6. Keshavarz H, Duffy SW, Sadeghi-Hassanabadi A, Zolghadr Z, Oboodi B. Risk factors for and relationship between bacterial vaginosis and cervicitis in a high risk population for cervicitis in Southern Iran. Eur J Epidemiol.
2001;17(1):89-95

7. Kenyon C, Colebunders R, Crucitti T. The global epidemiology of bacterial vaginosis: a systematic review. Am J Obstet Gynecol. 2013;209(6):505-523. doi:10.1016/j. ajog.2013.05.006.

8. Gallo MF, Macaluso M, Warner $L$, et al. Bacterial vaginosis, gonorrhea, and chlamydial infection among women attending a sexually transmitted disease clinic: a longitudinal analysis of possible causal links. Ann Epidemiol. 2012;22(3):213-220. doi: 10.1016/j.annepidem.2011.11.005.

9. Tavana Z, Hadaiegh M, Pourdast T. The effect of treatment of bacterial vaginosis on pregnancy outcome. Iran J Obstet Gyneocol Infertil. 2010;13(5):1-7.

10. Borjian S, Shojaei H, Shabanian M, Deris F. Diagnosis of Gardenella associated vaginosis in Borujen women's outpatient Clinic, 2000. J Shahrekord Univ Med Sci. 2002;3(4):38-44.

11. Löfmark S, Edlund C, Nord CE. Metronidazole is still the drug of choice for treatment of anaerobic infections. Clin Infect Dis. 2010;50 suppl 1:S16-S23. doi: 10.1086/647939.

12. Mohanty S, Sood S, Kapil A, Mittal S. Interobserver variation in the interpretation of Nugent scoring method for diagnosis of bacterial vaginosis. Indian J Med Res. 2010;131:88-91.

13. Datcu R, Gesink D, Mulvad G, et al. Bacterial vaginosis diagnosed by analysis of first-void-urine specimens. J Clin Microbiol. 2014;52(1):218-225. doi:10.1128/JCM.02347-13.

14. Berek JS. Novak's Gynecology. 13th ed. New York: Lippincott Williams \& Wilkins; 2002.

15. Hainer BL, Gibson MV. Vaginitis. Am Fam Physician. 2011;83(7):807-715.

16. Bodean O, Munteanu O, Cirstoiu C, Secara D, Cirstoiu M. Probiotics--a helpful additional therapy for bacterial vaginosis. J Med Life. 2013;6(4):434-436.

17. Hemalatha R, Mastromarino P, Ramalaxmi B, Balakrishna $\mathrm{N}$, Sesikeran B. Effectiveness of vaginal tablets containing lactobacilli versus $\mathrm{pH}$ tablets on vaginal health and inflammatory cytokines: a randomized, double-blind study. Eur J Clin Microbiol Infect Dis. 2012;31(11):3097-3105. doi:10.1007/s10096-012-1671-1.

18. Petersen EE, Magnani P. Efficacy and safety of vitamin C vaginal tablets in the treatment of non-specific vaginitis. A randomised, double blind, placebo-controlled study. Eur J Obstet Gynecol Reprod Biol. 2004;117(1):70-75.

19. Petersen EE, Genet M, Caserini M, Palmieri R. Efficacy of vitamin $C$ vaginal tablets in the treatment of bacterial vaginosis: a randomised, double blind, placebo controlled clinical trial. Arzneimittel-Forschung. 2011;61(4):260-265. doi:10.1055/s-0031-1296197.

20. Abbaspoor Z, Goodarzy F, Abbaspoor MR. Comparison of the effectiveness of vitamin $\mathrm{C}$ vaginal tablet with metronidazole vaginal gel in the treatment of bacterial vaginosis. African J Pharm Pharmacol. 2010;4(7):484-489.

21. Foruzan I. The role of religious tourism in the development and growth of urban metropolis: (In The Case of Mashhad, Iran) [Thesis]. Eastern Mediterranean University; 2014.

22. Fethers KA, Fairley CK, Hocking JS, Gurrin LC, Bradshaw CS. Sexual risk factors and bacterial vaginosis: a systematic review and meta-analysis. Clin Infect Dis. 2008;47(11):142635. doi: 10.1086/592974.

23. Spiegel C, Amsel R, Holmes K. Diagnosis of bacterial vaginosis by direct gram stain of vaginal fluid. J Clin Microbiol. 1983;18(1):170-177. 
24. Kusuma Naik A, Nusrat H, Krishna L, Kumar R. An RCT for efficacy of oral probiotics in treatment of cases with symptomatic white discharge per vagina in rural population. J South Asian Federation Obstet Gynaecol. 2012;4(3):126-129.

25. Nugent RP, Krohn MA, Hillier S. Reliability of diagnosing bacterial vaginosis is improved by a standardized method of gram stain interpretation. J Clin Microbiol. 1991;29(2):297301.

26. Datcu R, Gesink D, Mulvad G, et al. Bacterial vaginosis diagnosed by analysis of first-void-urine specimens. J Clin Microbiol. 2014;52(1):218-25. doi: 10.1128/JCM.02347-13.

27. Bohbot JM, Vicaut E, Fagnen D, Brauman M. Treatment of bacterial vaginosis: a multicenter, double-blind, double-dummy, randomised phase III study comparing secnidazole and metronidazole. Infect Dis Obstet Gynecol. 2010;2010:705692. doi:10.1155/2010/705692.
28. Krasnopolsky VN, Prilepskaya VN, Polatti F, et al. Efficacy of vitamin $\mathrm{C}$ vaginal tablets as prophylaxis for recurrent bacterial vaginosis: a randomised, double-blind, placebocontrolled clinical trial. J Clin Med Res. 2013;5(4):309-315. doi:10.4021/jocmr1489w.

29. Boskey ER, Telsch KM, Whaley KJ, Moench TR, Cone RA. Acid production by vaginal flora in vitro is consistent with the rate and extent of vaginal acidification. Infect Immun. 1999;67(10):5170-5175.

30. Togni G, Battini V, Bulgheroni A, Mailland F, Caserini $\mathrm{M}$, Mendling $\mathrm{W}$. In vitro activity of nifuratel on vaginal bacteria: could it be a good candidate for the treatment of bacterial vaginosis? Antimicrob Agents Chemother. 2011;55(5):2490-2492. doi:10.1128/AAC.01623-10.

31. Polatti F. Bacterial vaginosis, atopobium vaginae and nifuratel. Curr Clin Pharmacol. 2012;7(1):36-40.

Copyright @ 2017 The Author (s); This is an open-access article distributed under the terms of the Creative Commons Attribution License (http://creativecommons.org/licenses/by/4.0), which permits unrestricted use, distribution, and reproduction in any medium, provided the original work is properly cited. 